\title{
The New German Coal Laws: A Difficult Balancing Act
}

\author{
Louisa Raitbaur \\ Edinburgh Law School, University of Edinburgh, Edinburgh, UK \\ louisa.raitbaur@gmx.de
}

\begin{abstract}
The German government adopted a coal exit law in 2020. The law enshrines a coal exit pathway through to 2038 and provides for significant compensation for coal companies. An accompanying structural-support law is to create new prospects for coal regions and workers. The development of the laws involved participation by the public, experts, interest groups, and the German states. Concerns about just transition and climate justice played an important role. The final laws were nevertheless met with a significant degree of dissatisfaction from stakeholders across the political spectrum, science, industry, and NGOs. Flaws in the participation process and deviation from expert recommendations have been raised as criticisms. The climate ambition, economic rationale, and social-justice effects of the laws have been contested. Repeal of the laws in any substantive way nevertheless seems unlikely.
\end{abstract}

\section{Keywords}

German coal exit law - German structural-support law for coal regions - just transition - climate justice - public participation - interest-group influence

\section{Introduction}

An energy transition away from coal and toward renewables has characterized Germany's climate-change policies in recent decades and continues to be a challenge. The coal industry has long resisted governmental attempts to 
transition away from coal and has profited from massive state subsidies. ${ }^{1}$ In recent years, however, public opinion has turned against the industry, with the majority of the population in German coal-mining regions supporting the phasing out of coal. ${ }^{2}$ Additional pressure has come from Germany's obligation to work towards the Paris Agreement's goal of holding global warming to less than $2^{\circ} \mathrm{C}$, and preferably holding it at $1.5^{\circ} \mathrm{C}$. This led in 2016 to a governmental climate plan that set a compulsory emission reduction for the energy sector of $61 \%$ by 203 o below the 199 o level. ${ }^{3}$

In 2017 , an emission reduction of $29 \%$ below the 1990 level was achieved in the energy sector. ${ }^{4}$ In 2019 , Germany decreased its coal production by $22 \%$ from the previous year, as the last of the 'hard coal' mines were shut down. ${ }^{5}$ Yet Germany is still the world's largest producer of lignite coal after China, and remains a major importer of hard coal. ${ }^{6}$

In 2018, Germany failed several EU targets: its greenhouse-gas-emission levels were higher than its agreed share under the EU emission targets; the country did not reach its target for its share of renewable energy; and it did not sufficiently reduce its energy consumption. ${ }^{7}$ Coal was still the most important domestic energy source in 2019 , accounting for nearly $30 \%$ of electricity production. ${ }^{8}$ Additional measures are needed for Germany to achieve the 2030

1 Stefan Vögele, Paul Kunz, Dirk Rübbelke, and Theresa Stahlke, 'Transformation Pathways of Phasing out Coal-Fired Power Plants in Germany', 8 Energy, Sustainability and Society 1 (2018), 6 .

2 Tessa Coggio and Thane Gustafson, 'When the Exit? The Difficult Politics of German Coal', 130 German Politics and Society 47 (2019), 56; Martin Kittel, Leonard Goeke, Claudia Kemfert, Pao-Yu Oei, and Christian von Hirschhausen, 'Scenarios for Coal-Exit in Germany: A ModelBased Analysis and Implications in the European Context', 13 Energies 2041 (2020), 2.

3 See official information of the Federal Ministry for the Environment, Nature Conservation and Nuclear Safety, 31 January 2019, <www.bmu.de/themen/klima-energie/klimaschutz/nationaleklimapolitik/kommission-wachstum-strukturwandel-und-beschaeftigung/>; Katharina Baudisch and Dörte Fouquet, 'Germany's Coal Exit Plan: A Legal and Political Outline on How Germany Plans to Phase out Coal Fired Power Stations by 2038', 9 Renewable Energy Law and Policy Review 45 (2019), 46.

4 Kommission 'Wachstum, Strukturwandel und Beschäftigung', Abschlussbericht (January 2019), $<$ www.bmwi.de/Redaktion/DE/Downloads/A/abschlussbericht-kommission-wachstumstrukturwandel-und-beschaeftigung.pdf?_blob=publicationFile> (hereinafter Kommission 'Wachstum, Strukturwandel und Beschäftigung'), 12.

5 International Energy Agency, Coal 2020: Analysis and Forecast to 2025 (December 2020), 40.

6 Ibid, 48; see <www.statista.com/statistics/264779/countries-with-the-largest-soft-brown-coalproduction/>; <https://knoema.com/atlas/topics/Energy/Coal/Production-of-lignite-coal >.

7 European Environment Agency, Trends and Projections in Europe 2020: Tracking Progress Towards Europe's Climate and Energy Targets (2020), 14, 22, 34, 41.

8 See Statistisches Bundesamt, <www.destatis.de/DE/Presse/Pressemitteilungen/2021/o3/ PD21_101_43312.html>. 
target for the energy sector. Following the federal elections in 2017, the government initiated a legislative process for a coal exit. It resulted in a 2020 coal exit law (Kohleausstiegsgesetz), ${ }^{9}$ accompanied by a structural-support law for coal regions (Strukturstärkungsgesetz Kohleregionen). ${ }^{10}$

In this article, I outline the development, content, and legal context of the German coal exit and structural-support laws. I also look at the influence of various interest groups on the elaboration of these laws, and at their responses to the final outcome. An analysis of equity and climate-justice considerations in the coal exit and structural-support laws is also undertaken. I conclude with an assessment of whether a repeal or amendment of the laws is a likely prospect.

2

\section{Development and Content of the Coal Exit and Structural-Support} Laws

\subsection{Development}

In June 2018, the German government established the Commission for Growth, Structural Transformation, and Employment ('Coal Commission'), tasked to develop proposals for a gradual coal phase-out, to be accompanied by a sustainable structural transformation with employment-security options in coal regions. ${ }^{11}$ The Coal Commission submitted its final report in January $2019 .{ }^{12}$

The government published a first draft of the coal exit law in January $2020,{ }^{13}$ received responses from the Federal Council ${ }^{14}$ and the public, and adopted a draft law in February 2020. ${ }^{15}$ Next was the formal participation of the Federal

9 Gesetz zur Reduzierung und zur Beendigung der Kohleverstromung und zur Änderung weiterer Gesetze (Kohleausstiegsgesetz) vom 8. August 2020 (B GBl. I S. 1818).

10 Strukturstärkungsgesetz Kohleregionen vom 8. August 2020 (в B Bl. I S. 1795).

11 Baudisch and Fouqet, supra note 3, 45; Kommission 'Wachstum, Strukturwandel und Beschäftigung', supra note 4, 109.

12 Kommission 'Wachstum, Strukturwandel und Beschäftigung', supra note 4.

13 Gesetzesentwurf der Bundesregierung, 'Entwurf eines Gesetzes zur Reduzierung und zur Beendigung der Kohleverstromung und zur Änderung weiterer Gesetze (Kohleausstiegsgesetz)', <www.bmwi.de/Redaktion/DE/Downloads/G/gesetzentwurfkohleausstiegsgesetz.pdf?_blob=publicationFile\&v=8>.

14 The Federal Council is an assembly of representatives of the 16 German states. Its role in the law-making process is enshrined in the constitution: Bundesratsdrucksache 51/20 (31 January 2020).

15 Gesetzesentwurf der Bundesregierung, 'Entwurf eines Gesetzes zur Reduzierung und zur Beendigung der Kohleverstromung und zur Änderung weiterer Gesetze (Kohleausstiegsgesetz)', Bundestagsdrucksache 19/17342 (24 February 2020). 
Council in the legislative process, wherein it suggested amendments to the draft law; ${ }^{16}$ and the government then responded to the comments of the Federal Council. ${ }^{17}$

The first draft of the structural-support law had already been published by the government in August 2019. ${ }^{18}$ It was followed by a public-participation process; and the draft law was adopted in September 2019. ${ }^{19}$ The participation of the Federal Council with suggested amendments took place in October 2019. ${ }^{20}$

On the 3 July 2020, the coal exit law and the structural-support law were adopted by Parliament and the Federal Council. ${ }^{21}$ They entered into force on 14 August 2020. ${ }^{22}$

\subsection{Content}

The coal exit law enshrines a pathway for the phasing out of coal-based energy through to 2038 , when the last lignite mines and lignite and hard coal power plants must be shut down. The trajectory of the exit path is determined, in part, by specified maximum amounts of lignite coal production for 2022 and $2030 .{ }^{23}$ A central feature of the law is the compensation procedures for the affected mining companies and coal power plants. Up until 2026, operators of hard coal power plants may participate in yearly tenders in which they offer to shut down their plant voluntarily in exchange for a certain amount of compensation. The so-called Federal Network Agency follows a prescribed procedure to decide which operators win the bid. ${ }^{24}$ A maximum compensation amount is specified in the law. It declines with every year of the tender process, incentivizing operators to seek an early shut-down. As of 2027 , hard coal power plants are to be shut down by regulatory order without

16 Stellungnahme des Bundesrates, 'Entwurf eines Gesetzes zur Reduzierung und zur Beendigung der Kohleverstromung und zur Änderung weiterer Gesetze (Kohleausstiegsgesetz)', Bundesratsdrucksache 51/20 (13 March 2020).

17 Unterrichtung durch die Bundesregierung, Bundestagsdrucksache 19/18472 (8 April 2020).

18 Referentenentwurf des Bundesministeriums für Wirtschaft und Energie, Entwurf eines Strukturstärkungsgesetzes Kohleregionen, <www.bmwi.de/Redaktion/DE/Downloads/E/ entwurf-eines-strukturstaerkungsgesetzes-kohleregionen.pdf?_blob=publicationFile\& $\mathrm{v}=12>$.

19 Gesetzesentwurf der Bundesregierung, 'Entwurf eines Strukturstärkungsgesetzes Kohlregionen', Bundestagsdrucksache 19/13398 (23 September 2019).

20 Stellungnahme des Bundesrates, 'Entwurf eines Strukturstärkungsgesetzes Kohleregionen', Bundesratsdrucksache 400/19 (11 October 2019).

21 Gesetzesbeschluss des Deutschen Bundestages, Bundesratsdrucksache 392/20 (3 July 2020).

22 Kohleausstiegsgesetz Artikel 11; Strukturstärkungsgesetz Artikel 5.

23 Kohleausstiegsgesetz $\S \S 2$.

24 Kohleausstiegsgesetz $§ \S 18-19$. 
compensation. ${ }^{25}$ For each existing lignite coal mine and lignite coal power plant, an annex to the coal exit law specifies shutdown dates between 2020 and 2038. Operators of lignite coal mines and lignite coal power plants will receive compensation for shutting down as individually agreed in parliamentary-approved contracts with the government. ${ }^{26}$ Coal workers who are $5^{8}$ years old or older are eligible for financial support of up to five years to bridge the time until retirement. ${ }^{27}$ Resulting higher prices for electricity are to be prevented by subsidizing energy-grid costs and promoting heat and electricity cogeneration. ${ }^{28} \mathrm{~A}$ review process is to monitor the effects of the law on energy security and prices and assess the desirability of bringing back the exit date from 2038 to $2035 .^{29}$

The structural-support law aims to support economic development in the regions which will be affected by the coal exit. The four German states with historic hard coal mining regions-Mecklenburg-Western Pomerania, Lower Saxony, North Rhine-Westphalia, and Saarland-will receive a total of €1.o9 billion in financial aid from the federal government through to 2038 , to meet challenges of structural change and employment security. ${ }^{30}$ The four states with lignite coal mining regions-North Rhine-Westphalia, Brandenburg, Saxony, and Saxony-Anhalt-will receive a total of $€_{14}$ billion in financial aid from the federal government, to invest in economic and digital infrastructure and environmental protection. ${ }^{31}$ Additional direct payments from the federal level, as well as the establishment of certain federal agencies and research institutions to create jobs in underdeveloped hard coal and lignite coal regions may add another $€_{2} 6$ billion, resulting in a total investment of $€_{41}$.og billion in the structural transformation. ${ }^{32}$

\subsection{Legal Landscape}

Other laws and commitments which are relevant for the broader German energy transition are the 2019 Climate Protection Law specifying emission-reduction

25 Kohleausstiegsgesetz $\S \S 27-39$.

26 Kohleausstiegsgesetz §§40-50, notably §49; contracts have been negotiated and parliament approved them on 13 January 2021; see Federal Government, 'Von der Kohle hin zur Zukunft', $<$ www.bundesregierung.de/breg-de/themen/klimaschutz/kohleausstieg-1664496>.

27 Kohleausstiegsgesetz $§ 57$.

28 Kohleausstiegsgsetz §58, Artikel 4 Änderung des Energiewirtschaftsgesetzes.

29 Kohleausstiegsgesetz $§ \S 54-56$.

30 Strukturstärkungsgesetz $\S \S 11-13$.

$31 \quad$ Strukturstärkungsgesetz $\S \S 1,4,6$

32 Strukturstärkungsgesetz $§ \S 14-19$; Federal Government, 'Von der Kohle hin zur Zukunft', supra note 26 . 
goals, ${ }^{33}$ the 2014 Renewable Energies Law as amended in 2020, ${ }^{34}$ the 2011 amendments to the nuclear energy law to phase out nuclear energy, ${ }^{35}$ and Germany's international commitments under the Paris Agreement and European Union law.

The compensation processes for both hard coal and lignite coal companies are conditional on the approval of state aid by the European Commission. ${ }^{36}$ Emission certificates under the EU ETS, ${ }^{37}$ corresponding to the amount of emissions saved by shutting down coal power plants, are to be cancelled from the overall amount of available allowances, to achieve an emission-reduction effect at the European level. ${ }^{38}$

\section{Role of Interest Groups in the Development of the Two Laws}

In Germany, as elsewhere, when developing laws, the government is exposed to continuous lobbying and other attempts at exerting influence by interest groups such as industrial corporations and associations, labour unions, NGO s and citizen groups, political parties, and, in federated states, state governments. Citizens can be influential through demonstrations or protests. Public-participation processes are often enshrined formally in lawmaking, the rationale being, of course, that the involvement of interest groups from across society can confer further democratic legitimacy on a law, ${ }^{39}$ increasing acceptance and making a law 'sticky'.

33 Gesetz zur Einführung eines Bundes-Klimaschutzgesetzesund zur Änderung weiterer Vorschriften vom 12. Dezember 2019 (BGBl. I S. 2513).

34 Gesetz zur Änderung des Erneuerbare-Energien-Gesetzes und weiterer energierechtlicher Vorschriften vom 21. Dezember 2020 (в Bl. I S. 3138).

35 Dreizehntes Gesetz zur Änderung des Atomgesetzes vom 31. Juli 2011 (BG Bl. I S. 1704).

36 Kohleausstiegsgesetz, Artikel 1o Beihilferechtlicher Vorbehalt; Treaty on the Functioning of the European Union (TFEU) (adopted 13 December 2007) Official Journal C 326, 26/10/2012 P. oo01-039o articles 107-9.

37 Directive 2003/87/EC of the European Parliament and of the Council of 13 October 2003 Establishing a System for Greenhouse Gas Emission Allowance Trading Within the Union and Amending Council Directive 96/61/EC, Official Journal L 275, 25/10/2003, 32.

38 Kohleausstiegsgesetz, Artikel 2 Änderung des Treibhausgas-Emissionshandelsgesetzes; Coggio and Gustafson, supra note 2, 6o; Kittel et al., supra note 2, 3 .

39 See Southwest Network for Environmental and Economic Justice, Jemez Principles for Democratic Organizing (1996). 
3.1.1 The Coal Commission

The Coal Commission was tasked to reach a 'macrosocial consensus. ${ }^{40}$ For this reason, its members included politicians, scientists, energy-market representatives, labour unions, and environmental-protection organizations. ${ }^{41}$ The Commission's work was supported by representatives of several German states with a stake in the coal transition, and by representatives of eight ministries. ${ }^{42}$ Numerous experts from various scientific institutions, universities, coal companies, ministries, the EU Commission, NGOs, and regions were heard in the process. ${ }^{43}$ In its final report, commonly referred to as the 'coal compromise', the Coal Commission elaborated, among other things, on the economic, structural, and employment situation in the coal sector, possible measures and consequences for electricity prices, security of supply, employment, structural-development plans for different coal regions, and climate politics and protection. ${ }^{44}$ For the coal exit as such, the report outlines a phase-out pathway for hard coal power plants and lignite mines and power plants through to the end-date of 2038 .

\subsubsection{Public Participation}

In line with the regular legislative process in Germany, public submissions on the drafts of the coal exit law and the structural-support law were invited. ${ }^{45}$ Opinions were submitted by industrial associations, citizen's initiatives, labour unions, environmental NGOs, and consumer and employer associations.

For both draft laws, public participation was undermined by the remarkably short period-less than 24 hours-prescribed for making submissions. Various interest groups raised the complaint that stakeholders were thereby effectively hindered from participating constructively in the law-making process, frustrating the goal of finding a societal compromise- the stated reason for establishing the Coal Commission. ${ }^{46}$

40 Kommission 'Wachstum, Strukturwandel und Beschäftigung', supra note 4, 2.

41 Ibid, 6f.; Baudisch and Fouquet, supra note 3, 45 .

42 Kommission 'Wachstum, Strukturwandel und Beschäftigung', supra note 4, 110.

43 Ibid., 112ff.

44 Ibid.; Baudisch and Fouquet, supra note 3, 46ff.

45 For all submitted opinions, see <www.bmwi.de/Navigation/DE/Service/Stellungnahmen/ Kohleausstiegsgesetz/kohleausstiegsgesetz.html>; and <www.bmwi.de/Navigation/DE/ Service/Stellungnahmen/Strukturstaerkungsgesetz-Kohleregionen/stellungnahmenstrukturstaerkungsgesetz-kohleregionen.html>.

46 Deutscher Gewerkschaftsbund, Stellungnahme des Deutschen Gewerkschaftsbundes zum Referentenentwurf des Bundesministeriums für Wirtschaft und Energie zum Gesetz zur Reduzierung und zur Beendigung der Kohleverstromung und zur Änderung weiterer 
Following the allotted public participation period for the structural-support law on 21-22 August 2019, several stakeholders demanded that the government allow a longer period of public participation for the coal exit law. ${ }^{47}$ Nonetheless, the period's length (22-23January 2020) was the same. The Federal Ministry for Economic Affairs and Energy attempted to justify the tight deadlines by citing the time-pressures of the coal exit. ${ }^{48}$ However, this hardly justifies a 24-hour public participation in a legislative process that lasted in excess of two years. The impression cannot be avoided that the government sought to sidestep further debate on the hard-won 'compromise' reached in the Coal Commission, or on its subsequent deviations from that compromise (on which, more below). The public-participation process was reduced to a formality.

\subsubsection{Influence of Germany's State Governments}

Federal laws in Germany can be heavily influenced by the interests of constituent states. The states where the majority of the coal industry is located (North Rhine-Westphalia, Brandenburg, Saxony, and Saxony-Anhalt) were involved in the law-making process, over and above their participation in the Federal Council. The federal government separately sought the approval of the prime ministers of the four states for the plan for the coal phase-out, and it intends to negotiate an agreement with them for the implementation of the financial aid foreseen in the structural-support law. ${ }^{49}$ The approval of these states was

Gesetze (Kohleausstiegsgesetz) (23 January 2020), <www.bmwi.de/Redaktion/DE/ Downloads/Stellungnahmen/Stellungnahmen-Kohleausstiegsgesetz/dgb.pdf? _blob=publicationFile\&v=4>; ClientEarth, Stellungnahme zum Referentenentwurf des Bundesministeriums für Wirtschaft und Energie für ein Gesetz zur Reduzierung und zur Beendigung der Kohleverstromung und zur Änderung weiterer Gesetze (Kohleausstiegsgesetz) (23 January 2020), <www.bmwi.de/Redaktion/DE/Downloads/Stellungnahmen/ Stellungnahmen-Kohleausstiegsgesetz/client-earth.pdf?_blob=publicationFile\&v=4>; BUND (Friends of the Earth Germany), Stellungnahme zum Referentenentwurf des BMWI für ein "Strukturstärkungsgesetz Kohleregionen" (22 August 2019), <www.bmwi.de/ Redaktion/DE/Downloads/Stellungnahmen/Stellungnahmen-StrukturstaerkungsgesetzKohleregionen/bund.pdf?_blob=publicationFile\& $\&=4>$.

47 Ibid.; Bundesverband der Deutschen Industrie e.V., 'Stellungnahme des BDI zum Referentenentwurf des Strukturstärkungsgesetzes Kohleregionen' (22 August 2019), $<$ www.bmwi.de/Redaktion/DE/Downloads/Stellungnahmen/StellungnahmenStrukturstaerkungsgesetz-Kohleregionen/bdi.pdf?_blob=publicationFile $\& \mathrm{v}=4>$.

48 Michael Bauchmüller, 'Sie nennen es Beteiligung der Öffentlichkeit', Süddeutsche Zeitung, 27 January 2020, <www.sueddeutsche.de/wirtschaft/umweltpolitik-sie-nennenes-beteiligung-der-oeffentlichkeit-1.4773402>.

49 Press release of the Federal Government 'Bund-/Länder-Einigung zum Kohleausstieg' (16 January 2020), <www.bundesregierung.de/breg-de/aktuelles/bund-laender-einigungzum-kohleausstieg-1712774>. 
a crucial condition for passing the two laws. Political leaders in the four states had in the past strongly opposed any policy leading to the closure of coal mines or coal power plants. ${ }^{50}$

\subsubsection{Lobbying and Citizen Protest}

Extensive lobbying by the coal industry can be assumed, but a closer analysis is hindered by non-transparent procedures. ${ }^{51}$ Incumbent industries often hold a strong position from which to influence politicians and the legislative process, as they have built networks over decades. ${ }^{52}$ The coal industry usually invokes the threats of energy security and job losses to deter politicians from stricter regulation..$^{53}$

As already noted, in recent years, public opinion has turned against the industry. ${ }^{54}$ There has been significant public protest and civil disobedience. ${ }^{55}$ Activists have occupied or blocked access to coal mines and power plants and have tried to prevent the use of additional land for coal mining. The 'Hambi bleibt' protest is exemplary of 'anarchist resistance.'56 The Hambacher Forst, an ancient forest owned by RWE and threatened with deforestation for lignite mining, has been occupied since 2012, with activists living in tree houses and resisting repeated police attempts to clear the area. ${ }^{57}$ In addition, numerous NGO lawsuits have targeted administrative permits for RWE mining. ${ }^{58}$ This campaign effort succeeded, as the coal phase-out pathway avoids a

$5^{\circ}$ Coggio and Gustafson, supra note 2, $57 \mathrm{f}$.

$5^{1}$ A register for lobbying activities in parliament was established by a dedicated law on 25 March 2021; see <www.bundestag.de/dokumente/textarchiv/2021/kw12-de-lobbyregister-798182>.

52 Vögele et al., supra note 1, 7; Tobias Haas and Henrik Sander, 'Shortcomings and Perspectives of the German Energiewende', 30 Socialism and Democracy 121 (2016), 125; Jessica F. Green, 'The Existential Politics of Climate Change', Boston Review 38 (2020), 40; Leah C. Stokes, Short Circuiting Policy: Interest Groups and the Battle Over Clean Energy and Climate Policy in the American States (Oxford, UK: Oxford University Press, 2020), 3.

53 Vögele et al., supra note 1,7 .

54 Coggio and Gustafson, supra note 2, 56; Kittel et al., supra note 2, 2.

55 Emily Hammond, 'Toward a Role for Protest in Environmental Law', 7o Case Western Reserve Law Review 1039 (2020), 1043f.

56 Ricardo Kaufer and Paula Lein, 'Anarchist Resistance in the German Hambach Forest: Localising Climate Justice', 28 Anarchist Studies 6o (2020), 61.

57 See <https://hambachforest.org/background/whats-all-this-about/>, 61, 68; Haas and Sander, supra note 52,135 .

$5^{8}$ See <www.bund-nrw.de/themen/braunkohle/hintergruende-und-publikationen/ braunkohlentagebaue/hambach/bund-klagen-gegen-hambach/>; Kaufer and Lein, supra note 56,78 . 
destruction of the Hambacher Forst, in line with a recommendation of the Coal Commission. ${ }^{59}$

\subsection{Interest Groups' Responses to the Adopted Laws}

The coal exit law and the structural-support law were adopted on the same day and widely perceived as a package deal. The Christian Democratic (CDU) and Social Democratic (SPD) parties, which constitute the government, voted in favour of both laws. However, except for the Green party (Bündnis 9o/Die Grünen), which voted for the structural-support law, all other parties voted against the two laws. ${ }^{60}$ The Green party called the coal exit law a 'coal extension law' which prevents future governments from taking the necessary steps to reach the Paris Agreement's goals. The Left party (Die Linke) alleged that the laws had been made for the benefit of corporations instead of people and demanded a coal exit by 2030. The far right (AfD), on the other hand, called for postponing the coal exit to 2050 and raised questions about energy security. The neoliberal party (FDP) decried the insufficient incentives for private investment contained in the structural-support law. 61

Numerous stakeholders complained that the laws significantly deviated from the Coal Commission's compromise, at the expense of climate protection and of the people affected by opencast mining. ${ }^{62}$ The phase-out pathway for hard-coal use in power stations by 2038 does reflect the recommendations of the Coal Commission. ${ }^{63}$ Still, several environmental NGO s that participated in the Coal Commission and supported the coal compromise alleged in a minority motion that the climate ambition of the compromise was starkly insufficient and not in line with German and international climate goals. ${ }^{64}$ For lignite coal

59 Press release of the Federal Government, supra note 49; Kommission 'Wachstum, Strukturwandel und Beschäftigung', supra note 4, 63 .

6o See Deutscher Bundestag, 'Bundestag beschließt das Kohleausstiegsgesetz' (3 July 2020), $<$ www.bundestag.de/dokumente/textarchiv/2020/kw27-de-kohleausstieg-701804>.

61 See Deutscher Bundestag, supra note 6o.

62 WWF, 'StellungnahmedeswWF Deutschland-Referentenentwurf zumKohleausstiegsgesetz: Gesetz zur Reduzierung und Beendigung der Kohleverstromung' (23 January 2020), $<$ www.bmwi.de/Redaktion/DE/Downloads/Stellungnahmen/StellungnahmenKohleausstiegsgesetz/wwf-deutschland.pdf?_blob=publicationFile\&v=4>; Claudia Kemfert 'Verschleppter Kohleausstieg: Erreichen der Klimaziele rückt in weite Ferne: Kommentar', German Institute for Economic Research (DWI Berlin) weekly report 8/2020, 116, <www. diw.de/de/diw_ol.c.739033.de/publikationen/wochenberichte/202O_08_3/verschleppter_ kohleausstieg_erreichen_der_klimaziele_rueckt_in_weite_ferne_kommentar.html>.

63 Kommission 'Wachstum, Strukturwandel und Beschäftigung', supra note 4, 63f.

64 BUND (Friends of the Earth Germany), BUND-Stellungnahme zum Referentenentwurf des Bundesministeriums für Wirtschaft und Energie des Gesetzes zur Reduzierung und 
power plants, the compromise foresaw a linear and continuous reduction of production capacity from 2020 through to $2038 .{ }^{65}$ The coal exit law abandons this trajectory. Annex II of the law lists the overall installed lignite coal power plant capacity in 2020 as 17,249 MW. Of this, plants with a combined capacity of just 3,153 MW are scheduled to be shut between 2020 and 2027. In 2028 and 2029 , directly before the specified maximum amount for coal production in 2030 is to be reached, plants with a capacity of $4,737 \mathrm{MW}$ are to be taken off the grid. No closures are scheduled for 2030-2032. Plants with a capacity of $3,298 \mathrm{MW}$ will be shut down over the period 2033-2035. The remaining plants, with 6,061 MW combined capacity, are all scheduled to be terminated in 2038 , the year of the coal exit. ${ }^{66}$ It is noteworthy that over $35 \%$ of the initial capacity of lignite coal power plants will remain on the grid until 2038. According to BUND, an NGO, total emissions from this staged closure pathway are much higher than those that would have resulted from the Coal Commission's linear trajectory pathway. ${ }^{67}$

Moreover, economists have claimed that the massive payments to the coal industry are unjustifiable, given that in Germany coal is not profitable anymore and cannot compete with renewables on the cost of electricity generation, ${ }^{68}$ and that the EU ETS makes the compensated phase-out in the coal exit law redundant, as the 'phase-out would happen anyway over the medium term as the price of carbon rises-possibly even sooner than currently planned'69 Moreover, many of the coal power plants that will receive compensation might have to be shut down anyway as they do not comply with new EU limits for nitrogen oxide and mercury emissions. ${ }^{70}$ In contrast, labour-union

zur Beendigung der Kohleverstromung und zur Änderung weiterer Gesetze (23 January 2020), <www.bmwi.de/Redaktion/DE/Downloads/Stellungnahmen/StellungnahmenKohleausstiegsgesetz/bund.pdf?_blob=publicationFile\&v=4>.

65 Kommission 'Wachstum, Strukturwandel und Beschäftigung', supra note 4, 63.

66 Kohleausstiegsgesetz, Annex 2.

67 BUND (Friends of the Earth Germany), supra note 64.

68 Comment by Claudia Kemfert of the German Institute for Economic Research (DIw Berlin), 'Umweltverbände und Experten kritisieren Kohleausstiegsgesetz', BR24 (o3 July 2020), $<$ www.br.de/nachrichten/deutschland-welt/umweltverbaende-und-experten-kritisierenkohleausstiegsgesetz,S3ed9G5>; see also Béla Galgóczi, Phasing Out Coal: A Just Transition Approach (Working Paper Series No. 2019.04, European Trade Union Institute, Brussels, 2019), 17 .

69 German Council of Economic Experts, 'Setting out for a New Climate Policy: Special Report', 39, <www.sachverstaendigenrat-wirtschaft.de/en/special-report-2019.html>.

70 Kommission 'Wachstum, Strukturwandel und Beschäftigung', supra note 4, 19; Directive 2010/75/EU of the European Parliament and of the Council of 24 November 2010 On Industrial Emissions (Integrated Pollution Prevention and Control), Official Journal L 334/17 17.12.2010, in combination with BREF standards, <https://eippcb.jrc.ec.europa.eu/sites/ 
representatives lamented that, from 2027 onward, coal power plants will be shut down without compensation, with implications for coal workers. ${ }^{71}$

Environmental NGO s and activists have sharply attacked the coal exit law. Even though Greenpeace participated in the Coal Commission, its members protested the law by climbing onto the roof of the federal parliament building and unfurling a banner demanding a future without coal. ${ }^{72}$ Several NGO s have criticized the coal exit law on the grounds that it allows the newly built hard coal power plant 'Datteln 4' to start operating, contrary to the Coal Commission's recommendations. ${ }^{73}$ The government has pointed out that it makes more sense to put a new, highly efficient plant into operation and to shut down older, less efficient ones with equivalent capacity earlier than their due date. ${ }^{74}$ The NGO ClientEarth argued against this retort that the capacity of a power plant (the maximum amount of electricity it can produce under ideal conditions $)^{75}$ does not necessarily mirror its actual emissions, and that the operation of a new power plant with a higher utilization rate could, despite its higher efficiency, potentially lead to higher emissions than the operation of older plants with equivalent capacity. ${ }^{76}$

\section{Equity Considerations in the Two Laws}

The transition away from climate-damaging coal can threaten jobs and deepen already existing distributional inequalities. ${ }^{77}$ This estranges significant parts of the population from the climate movement, weakening the prospects of

default/files/2019-11/JRC_107769_LCPBref_2017.pdf>; Vögele et al., supra note 1, 7; Galgóczi, 'Phasing Out Coal', supra note 68, $14 \mathrm{f}$.

Stellungnahme Deutscher Gewerkschaftsbund, supra note 46 .

72 Tagesschau 'Kohleausstieg bis 2038 ist beschlossen' (3 July 2020), <www.tagesschau.de/ inland/bundestag-kohleausstieg-10g.html>.

73 Kohleausstiegsgesetz §53; Kommission 'Wachstum, Strukturwandel und Beschäftigung', supra note 4,62 .

74 Publication of the Federal Ministry for Economic Affairs and Energy, Kohleausstiegsgesetz: Umsetzung der Beschlüsse der Kommission "Wachstum, Strukturwandel und Beschäftigung" (28 January 2020), <www.bmwi.de/Redaktion/DE/Downloads/J-L/kohleausstiegsgesetzumsetzung-der-beschluesse-der-kommission.pdf?_blob=publicationFile\&v=6>.

75 See $<$ www.eia.gov/tools/faqs/faq.php?id=101\&t $=3>$.

76 Stellungnahme ClientEarth, supra note 46.

77 Ann M. Eisenberg, 'Just Transitions', 92 Southern California Law Review 273 (2019), 274f., 282ff.; Béla Galgóczi, 'Just Transition on the Ground: Challenges and Opportunities for Social Dialogue', 26 European Journal of Industrial Relations 367 (2020), $367 f$. 
climate action. ${ }^{78}$ To address this, climate activism and regulation have sought to adopt the concepts of 'just transition' and 'climate justice. ${ }^{79}$ While just transition sometimes focuses more narrowly on supporting workers in declining fossil-fuel industries, ${ }^{80}$ climate justice encompasses distributional consequences across society as a whole. ${ }^{81}$ The Coal Commission acknowledged these concepts and aimed to gain societal support for the coal exit through a balanced and equitable distribution of benefits and burdens. ${ }^{82}$

\subsection{Just Transition}

The issues arising from a German coal exit are exemplary of just-transition concerns. Between 1950 and 199o, hundreds of thousands of people worked in the coal industry, ${ }^{83}$ and historic coal regions and cities maintain a strong solidarity with coal miners. Jobs in the coal sector have long played a prominent role in debates about the German energy transition, perhaps disproportionate to the actual number of people affected. In the last two decades, the size of the workforce in the coal industry has declined sharply; in 2020, only 19,500 workers were left in lignite coal mines and lignite power plants. ${ }^{84}$ Mining for hard coal ended in 2018, as noted earlier, for economic reasons. ${ }^{85}$ Roughly 9,000 people continue to work in hard coal power plants. ${ }^{86}$ In total, around 28,500 workers (less than $0.1 \%$ of employed persons in Germany) ${ }^{87}$ need a new perspective after the coal exit. In recent years, even labour unions, which have long opposed a phase-out, have been focusing on how to conduct a coal phase-out

78 Sidney A. Shapiro and Robert R. M. Verchick, 'Inequality, Social Resilience, and the Green Economy', 86 UMKC Law Review 963 (2018), 3, 28.

79 Jedediah Purdy, 'The Long Environmental Justice Movement', 44 Ecology Law Quarterly 809 (2018), 8o9, 818ff.; Galgóczi, 'Just Transition on the Ground', supra note 77, 367.

80 Eisenberg, supra note $77,275 \mathrm{ff}$.

81 Referring to the broader issue of environmental justice, see Shapiro and Verchick, supra note 78,17 ; Purdy, supra note 79 at 864; Galgóczi, 'Phasing out Coal', supra note 68, 27.

82 Kommission 'Wachstum, Strukturwandel und Beschäftigung', supra note 4, 5 .

83 See <https://de.statista.com/statistik/daten/studie/161209/umfrage/braunkohlen bergbau-beschaeftigte-in-deutschland-seit-1950/>.

84 See <https://de.statista.com/statistik/daten/studie/161209/umfrage/braunkohlenbergbaubeschaeftigte-in-deutschland-seit-195/>; Galgóczi, 'Phasing out Coal', supra note 68, 11.

85 See <https://de.statista.com/infografik/15437/beschaeftigten-im-steinkohlebergbau-indeutschland/>; Coggio and Gustafson, supra note 2, 48.

86 See Tagesschau, 'Wie läuft das eigentlch mit der Kohle?' (3 July 2019) < www.tagesschau.de/ inland/zahlen-kohle-1o1.html>.

87 In April 2021, Germany had 44.5 million people in employment; see $<$ https://de.statista.com/statistik/daten/studie/1376/umfrage/anzahl-der-erwerbstaetigenmit-wohnort-in-deutschland/>. 
with a low impact on the labour market. ${ }^{88}$ The slow and gradual exit foreseen in the coal exit law is regarded as a just transition approach in itself. ${ }^{89}$ Over half of the workers in the coal industry are over $5^{0}$ years old..$^{90}$ Therefore, many of those who will lose their jobs by 2038 will be close to retirement age, and will thus receive the financial support foreseen in the coal exit law to supplement their unemployment benefits until they reach retirement age.

However, this is the only direct support foreseen in the coal exit and structural-support laws. The latter law focuses on creating new jobs in historic coal regions through general infrastructure development. But the availability of new employment opportunities does not guarantee that former coal workers will be able to transfer their skills or be successful in obtaining another job. ${ }^{91}$ Even if they do, their conditions might worsen, as labour unions in the past managed to secure relatively good labour conditions and wages in the coal industry. ${ }^{92}$ The Coal Commission recommended that the government provide further direct support for coal workers, such as targeted education and training and compensation for lower wages, ${ }^{93}$ but these were not included in the final laws.

\subsection{Climate Justice}

As coal mines, as well as power plants, are concentrated in only a few German regions, closing them does not only have important repercussions for local employment, it also affects individual purchase power and corporate tax revenues for municipalities in those regions. ${ }^{94}$ As explained earlier, the structuralsupport law provides significant financial support for the development of those regions, to alleviate the burden of the energy transition. The responsibility for the support measures is distributed between the federal government, the states, and municipalities. This favours achieving climate justice, as the federal government can monitor the overall picture, while the subnational governance levels are better able to assess and address local needs. Thus it should be possible to create new tax revenues and new forms of employment, in addition to a healthier environment. ${ }^{95}$ From a climate-justice viewpoint, the structural-support law is a positive development, as it promotes the ongoing

88 Vögele et al., supra note 1, 10.

89 Galgóczi, 'Just Transition on the Ground', supra note 77, 375.

90 See <www.wissenschaft.de/umwelt-natur/wie-viele-arbeitsplaetze-kostet-der-ausstieg/>.

91 Shapiro and Verchick, supra note 78, 1, 21.

92 Haas and Sander, supra note $52,136$.

93 Kommission 'Wachstum, Strukturwandel und Beschäftigung', supra note 4, 70, 97ff.

94 Vögele et al., supra note 1, 2, 7, 13; Galgóczi, 'Phasing out Coal', supra note 68, 25, 39.

95 Haas and Sander, supra note $52,136$. 
and internationally acclaimed social transformation of German coal regions into modern economic regions. ${ }^{96}$

However, two issues remain. Public outrage was triggered by the coal exit law's designation of the Garzweiler opencast lignite mine as indispensable for energy security and the economy. ${ }^{97}$ This leaves five small villages threatened with demolition, in order to make way for the approved expansion of the mine. ${ }^{98}$ In the last seventy years, ten small villages have been demolished and relocated for this mine, with the demolition of the most recent one carried out in 2021. ${ }^{99}$ From 1945 until today, 120,00o people across Germany have been affected by relocations of their villages due to opencast mining. ${ }^{100}$ Affected citizens have fought the relocations, and continue to fight to save the still-threatened villages, supported by NGO s and relying on human-rights law to sue companies such as RWE, which owns the Garzweiler mine. ${ }^{101}$ In this particular case, after numerous court actions challenging land expropriations were largely unsuccessful, activists including the civil-disobedience movement 'Ende Gelände' focused on blocking access to the Garzweiler mining site and to coal transports, and even occupied the mine itself. ${ }^{102}$ This form of protest is likely to continue.

The second issue is the potentially higher electricity prices for energy consumers due to the coal phase-out. Higher prices disproportionally affect lowerincome households and can lead to energy poverty. The coal exit law seeks to avoid higher prices for energy consumers. However, its measures are more focused on companies with high electricity demand whose international competitiveness needs to be secured through subsidies. ${ }^{103}$ Recent amendments

96 Galgóczi, 'Just Transition on the Ground', supra note 77, 375 .

$97 \quad$ Kohleausstiegsgesetz $§ 48$.

98 See information of the citizen's initiative 'Alle Dörfer bleiben!', <www.alle-doerfer-bleiben. de/doerfer/>; Kommission 'Wachstum, Strukturwandel und Beschäftigung', supra note 4, 42; see official information of mine owner RWE, <www.group.rwe/nachbarschaft/rwe-vorort/umsiedlung/?list1=Keyenberg\%2FKuckum\%2FUnterwestrich\%2FOberwestrich\%2FB erverath\&list $2=^{*}>$.

99 See official information of mine owner RwE, <www.group.rwe/nachbarschaft/rwe-vor-ort/ umsiedlung/abgeschlossene-umsiedlungen $>$.

100 Kommission 'Wachstum, Strukturwandel und Beschäftigung', supra note 4, 4.

101 ClientEarth Communications '\#HomesNotCoal: How Villagers Are Using the Law to Take on Lignite Mining in Germany' (18 November 2019), <www.clientearth.org/latest/latestupdates/stories/homesnotcoal-how-villagers-are-using-the-law-to-take-on-lignite-miningin-germany/>.

102 Kaufer and Lein, supra note 56, 76; <www.ende-gelaende.org/en/>; Haas and Sander, supra note 52,135 .

103 Press release of the Federal Government, supra note 49; Kohleausstiegsgesetz §55(5). 
to the Renewable Energies Law to promote energy efficiency in buildings and prolong state support for solar installations ${ }^{104}$ will contribute to stable electricity prices for households. On the other hand, the expansion of wind energy in Germany is hindered by extremely strict distance requirements of wind generators from settlements. ${ }^{105}$ Planned additional gas power plant capacity ${ }^{106}$ will contribute to lowering electricity prices-but at the expense of more greenhouse gas emissions. Germany exports a significant amount of domestically generated electricity; thus domestic electricity shortages and higher electricity prices due to reduced electricity generation through coal could be avoided by redirecting some of the exported electricity to the domestic market. ${ }^{107}$ The subsidies for electricity-grid costs specified in the coal exit law should help to keep electricity prices at their current level for everyone. ${ }^{108}$

\section{$5 \quad$ Outlook}

The coal exit and structural-support laws have been lauded by some for their extensive social engagement, especially through the Coal Commission, ${ }^{109}$ but this is not the general view. While legislation of complex societal matters inevitably draws criticism from stakeholders, the dissatisfaction in this case-especially with the coal exit law-is exceptionally high. The two laws had a chance to become a model of inclusive law-making. The engagement of the Coal Commission introduced expert knowledge and a holistic approach, something politicians may lack in the development of climate law. The government missed this opportunity, but it may also have damaged the legitimacy of these laws. Where the public and the private sector are encouraged to participate in the law-making process and negotiate a fair, society-wide compromise, from which the government then deviates, public participation is an empty gesture. This endangers the acceptance of the laws, leaving them as targets for repeal by dissatisfied stakeholders, who seek to overturn or weaken the laws. ${ }^{110}$

\footnotetext{
104 Press release of the Federal Government, supra note 49.

105 Gesetz zur Vereinheitlichung des Energieeinsparrechts für Gebäude und zur Änderung weiterer Gesetze vom 8. August 2020 (B G Bl. I S. 1728) Artikel 2.

106 Press release of the Federal Government, supra note 49.

107 Kittel et al., supra note 2, 7 f.

108 Agora Energiewende and Aurora Energy Research, 'The German Coal Commission: A Roadmap for a Just Transition from Coal to Renewables: Analysis', 7 .

109 Galgóczi, 'Just Transition on the Ground', supra note 77, 376.

110 Stokes, supra note 52,7 .
} 
Repeal, or at least amendment, of the coal exit law might be desirable, given that scientists and environmental NGOs believe that its climate ambition is insufficient and will impede Germany's contribution to the Paris Agreement's goals. ${ }^{111}$ NGO s have argued that the coal end-date in 2038 makes the German phase-out plan look more like a forced prolongment of coal use, as other Western European countries, such as the United Kingdom and France, will exit coal in the next few years. ${ }^{112}$ But such a comparison seems unduly simplistic, given the unique circumstances of countries. It should be recognized that Germany is simultaneously phasing out nuclear energy, which France, especially, relies on heavily. ${ }^{113}$ It is problematic that the coal exit law enshrines a precise pathway for the coal phase-out and that the review process of the law could at most bring the exit forward to 2035. The coal exit law stands in the way of a faster coal exit if more ambitious climate goals were adopted in the coming years, or if technological developments were to make a faster energy transition feasible. ${ }^{114}$ As mentioned above, the coal exit law was based on the climate plan adopted by the government in 2016, which used an emissionreduction target for the energy sector of $61 \%$ by 2030 below the 1990 level. ${ }^{115}$ Yet, in December 2020 the European Union raised its overall target from a $40 \%$ to a $55 \%$ per cent reduction by 2030 below 1990 , with repercussions for Germany's future energy-sector targets. 116

The negative effects of a repeal of the coal exit law on just transition and climate justice would be limited, as these issues are predominantly addressed by the structural-support law. The extensive funds made available through this law to develop economic and digital infrastructure, as well as the federal institutions that will be established in underdeveloped regions, will create

111 Claudia Kemfert, supra note 62; Stellungnahme ClientEarth, supra note 46.

112 John Parnell, 'Germany Set to Start Coal Phaseout Tenders Amid Legal Challenge', gtm (Green Tech Media), 27 August 2020, <www.greentechmedia.com/articles/read/germanyset-to-start-coal-phase-out-tenders-amid-legal-challenge>; Galgóczi, 'Phasing out Coal', supra note 68 , 21ff.

113 Germany claims to be the only major industrialized country simultaneously phasing out nuclear and coal energy: speech of Peter Altmaier, Federal Minister for Economic Affairs and Energy (3 July 2020), <www.bmwi.de/Redaktion/DE/Reden/2020/20200703-altmaierstrukturstaerkungsgesetz-bundestag.html >.

114 BUND (Friends of the Earth Germany), supra note 64.

115 Official information of the Federal Ministry for the Environment, Nature Conservation and Nuclear Safety, 31 January 2019, <www.bmu.de/themen/klima-energie/klimaschutz/ nationale-klimapolitik/kommission-wachstum-strukturwandel-und-beschaeftigung/>; Baudisch and Fouquet, supra note 3, 46 .

116 European Commission, Daily News 11/12/2020, <https://ec.europa.eu/commission/ presscorner/detail/en/mex_2O_2389>; the raised EU target has repercussions for the German domestic targets: Kittel et al., supra note 2, at 15 . 
jobs, improve the liveability of cities, and potentially give start-up support for entirely new industries. ${ }^{117}$ The people, municipalities, and industries that profit from this support will give positive policy feedback and resist any repeal, creating a path dependency or lock-in effect. ${ }^{118}$ The split of coal exit and just transition across two different laws might make a repeal of the coal exit law easier, as it does not profit from those path-dependency effects.

Nevertheless, a substantial repeal of the coal exit law seems unlikely. The law itself is well designed to prevent a repeal. The clear timeline for the coal phase-out creates legitimate expectations for coal companies, which in turn could lead them to sue the federal government for even higher compensation, should a subsequent government change that timeline. The coal exit law has overcome its first potential pitfall: the EU Commission, in November 2020 , approved the tender system for compensating hard coal power plants, enabling the first bidding round and the closure of the first plants in 2020.119 However, an in-depth investigation of the contractually agreed compensation for companies operating lignite coal mines is ongoing, and the EU Commission has voiced doubts about whether the measure is in line with EU state-aid rules, particularly the compensation for alleged forgone profits. ${ }^{120}$

Despite widespread dissatisfaction, it is unlikely that many stakeholders will really push for a repeal of the coal exit law. The coal industry seems to have accepted the coal exit as inevitable. While some coal companies have already sued the government for better compensation, they do not seek to block the law or delay its implementation. ${ }^{121}$ Labour unions will focus on the implementation of the structural-support law. NGO s and citizen protests might try to overturn the coal exit law, but their prospects of success considering the lock-in mechanisms in the law are slim.

Kommission 'Wachstum, Strukturwandel und Beschäftigung', supra note 4, 86ff. Stokes, supra note 52,3 f.

Press release of the Federal Government, 'Europäische Kommission genehmigt Steinkohle-Ausstieg' (25 November 2020), <www.bmwi.de/Redaktion/DE/Pressemitteilu ngen/202O/11/20201125-europaeische-kommission-genehmigt-steinkohle-ausstieg.html>; Press Release of the Federal Government, 'Altmaier: 'Erste Kohlekraftwerke gehen wie geplant noch in diesem Jahr vom Netz' (1 December 2020), <www.bmwi.de/Redaktion/ DE/Pressemitteilungen/2020/12/20201201-altmaier-erste-kohlekraftwerke-gehen-wiegeplant-noch-in-diesem-jahr-vom-netz.html>.

European Commission Press release 'State aid: Commission Opens In-Depth Investigation Into Compensation For Early Closure of Lignite-Fired Power Plants in Germany' (2 March 2021), <https://ec.europa.eu/commission/presscorner/detail/en/ip_21_972>.

Alex Dziadosz, 'German Hard Coal Company Suing for Better Phase-Out Compensation', Clean Energy Wire Journalism For the Energy Transition, 30 July 2020, <www. cleanenergywire.org/news/german-steag-suing-better-coal-exit-compensation>. 
What might seriously put the coal exit law up for discussion again would be a participation of the Green party in government after the 2021 federal elections. Rather than repealing the entire law, the Greens would probably try to amend and speed up the phase-out timeline. ${ }^{122}$ Regardless of the fate of the coal exit law, some expect that market forces and other factors might lead to a German coal exit well before 2038. ${ }^{123}$

122 Camilla Naschert, 'Market Reassured by Germany's Coal Exit Plan, But Questions Remain', S\&P Global Market Intelligence, 17 January 2020, <www.spglobal.com/marketintelligence/ en/news-insights/trending/vixwakvwsc_zmirzv5uvjq2>.

123 See $<$ https://beyond-coal.eu/coal-exit-tracker/?type=maps\&layer=4 $>$. 